\title{
Retirement Trajectories in Countries with Flexible Retirement Policies but Different Welfare Regimes
}

\author{
Isabel Baumann, Ignacio Madero-Cabib
}

\begin{abstract}
We examine how both the welfare regime and health affect retirement trajectories in countries with flexible retirement policies using longitudinal methods and harmonized panel data from two social-democratic (Sweden and Denmark) and two liberal welfare regimes (Chile and the United States). An early retirement trajectory, which represents retirement in the early $60 \mathrm{~s}$, is the most frequent in all countries, although it is less prevalent in liberal than in social-democratic regimes. Adverse health conditions are more frequent among early retirees in liberal but not in socialdemocratic regimes. Overall, we do not find evidence for an inciting effect of flexible retirement policies on working life extension. However, welfare regimes substantially affect late-life labor force participation.
\end{abstract}

Keywords: Flexible retirement policies, working life extension, welfare regimes, health, sequence analysis 


\section{Introduction}

In the context of increased financial pressure on old-age pension systems, flexible retirement policies (FRPs) have gained importance. FRPs primarily aim to relax such constraints as mandatory retirement ages and allow for the combination of (part-time) paid work and pension benefit receipts to prolong working lives and counteract early retirement trends, which were prevalent between the 1970s and the early 2000s (Hofäcker, Hess, \& König, 2016; Organization for Economic Co-operation and Development [OECD], 2017). However, only studies from the United States (U.S.) have found an inciting effect on working life extension (Charles \& Decicca, 2007; Johnson, 2011); research from other countries does not support this evidence. For instance, a recent study based on data from several OECD countries has shown that, although the introduction of FRPs leads, on average, to later retirement, average hours worked decreased and the total labor volume — on which old-age pension contributions are based-remained the same (Börsch-Supan, Bucher-Koenen, Kutlu-Koc, \& Goll, 2018). This leads to the question of whether the welfare regime to which a country belongs may explain these heterogeneous cross-national findings.

In recent decades, 'conventional retirement transitions', consisting of permanent labor market exits at statutory ages after working in long-term full-time jobs, have become less important. Instead, we observe an increasing de-standardization of retirement transitions, with individuals continuing to work after retirement, retiring after long-term inactivity or unemployment, or 'unretiring' (Baumann, 2016; Platts et al., 2017). This development calls for a methodological approach that allows an examination of retirement not as a one-time shift from full-time employment to full-time retirement but, rather, as a transition process that unfolds in the years leading up to and beyond the ages of statutory retirement (Calvo, Madero-Cabib, \& 
Staudinger, 2018; Duberley \& Carmichael, 2016; Wahrendorf, Zaninotto, Hoven, Head, \& Carr, 2017). In this study, we use a trajectory approach, which allows us to not only take the variation in individuals' retirement patterns into account but also to study retirement as a long-term process.

We aim to contribute to the literature on aging and social policy, exploring retirement trajectories in countries with FRPs and understanding, first, how dependent these trajectories are on the broader context of the welfare regime in which they are embedded. To achieve this, we examine retirement trajectories in four OECD countries with FRPs: two social-democratic countries (Sweden and Denmark) and two liberal countries (the U.S. and Chile). Since we use only two countries for each type of welfare regime, we cannot generalize the results. Nevertheless, the use of the welfare regime typology provides a useful analytical tool for achieving improved understanding of how the encompassing policy arrangements of welfare regime affect retirement trajectories. Second, assuming that the retirement process in countries with FRPs may be particularly influenced by individuals' health conditions, we also examine how health is associated with retirement trajectories. Yet, once again, we expect that this relationship may depend on the welfare regime, as workers with adverse health conditions may have a greater chance to retire early in social-democratic welfare regimes than in liberal welfare regimes, due to differences in the availability and generosity of welfare benefits (Hofäcker et al., 2016).

To examine these two dimensions of retirement trajectories in the four countries of interest, we draw on a harmonized dataset from the Survey of Health, Ageing and Retirement in Europe (SHARE) for Sweden and Denmark, the Health and Retirement Study (HRS) for the U.S., and the Chilean Social Protection Survey (EPS) for Chile. We model types of retirement trajectories between ages 60 and 70 during the same chronological period (i.e. the 10-year period from 2004 to $2014 / 2015$ ) using sequence and cluster analyses. We then analyze the association of welfare 
regimes and health conditions with the types of retirement trajectories using multinomial regression analysis.

\section{Flexible Retirement Policies and Welfare Regimes}

FRPs are characterized by two main features. The first is the timing of retirement: whether workers are allowed to draw their pensions before or after the statutory eligibility age (SEA). Second, FRPs enable the linkage of work and retirement, for instance, by facilitating a gradual transition from employment to retirement through a combination of part-time work and part-time retirement (OECD, 2017).

Flexible retirement schemes are widespread and are becoming more important as most countries reform their early retirement programs. All OECD countries allow retirees to engage in paid employment, yet less than one-fifth of retirees between ages 60 and 69 receive pension benefits while in paid employment (OECD, 2017) and the conditions of flexible retirement vary greatly between countries. Some countries impose limits on post-retirement earnings above which pension benefits are reduced, whereas most countries recalculate working retirees' pension benefits each year to take additional contributions into account (OECD, 2017). While the latter type of policy encourages employment beyond SEA, the former policy tends to have an attenuating effect on employment in late life..

FRPs are popular among both workers and employers (Eurofound, 2016). However, there is a gap between preferences for flexible retirement options and the choices that potential retirees make (OECD, 2018). One of the factors that influences retirement timing may be whether living expenses can be met after retirement, since countries differ with respect to the pre-retirement income replacement rates of their old-age pension schemes and workers may be obliged to work longer to meet their needs in some countries compared to others. A useful analytical tool to 
understand these cross-national differences is the typology of welfare regimes proposed by EspingAndersen (1990). This typology is based on the level of decommodification of labor and suggests that the higher the level of decommodification, the higher the redistribution. On one extreme of the welfare spectrum are the liberal countries (Shuey \& O'Rand, 2004), which usually feature means-tested welfare benefits, low levels of redistribution, and low average replacement rates of old-age pensions. On the opposite side of the spectrum, social-democratic countries promote high levels of redistribution through generous and universal welfare benefits (Fritzell \& Lundberg, 2007).

The type of welfare regime may be particularly relevant for workers with adverse health conditions. In fact, a large body of literature shows that workers with health problems tend to exit the labor force earlier worldwide. An analysis of the United Kingdom Whitehall II cohort study showed that workers with both poor mental health and poor physical functioning were highly likely to retire early (Jokela, Head, Vahtera, Westerlund, \& Marmot, 2010). Examining the association between different retirement patterns and cardiovascular diseases, a study based on data from the HRS reported worse health outcomes for those who retired early or at the statutory age than for those who retired later (Diaz-Toro, Madero-Cabib, Calvo, \& Staudinger, 2018). A recent study from Australia examining labor force participation rates after age 65 found that workers with chronic health conditions were significantly less likely to be employed (Schofield, Callander, Kelly, \& Shrestha, 2017). This study further showed that low-income workers were prone to be employed after 65 , suggesting that those who experience financial hardship tend to extend their working lives. Accordingly, if the institutional context does not provide them with the necessary support, workers with adverse health conditions may be confronted with additional hardship. Although a substantial body of literature indicates that welfare state institutions also matter for 
individuals with other types of vulnerability (Esping-Andersen, 1990; Gallie \& Paugam, 2000; Spini, Bernardi, \& Oris, 2017), in the present paper we focus on health-related vulnerability.

\section{Retirement Schemes of the Countries Studied}

First, the Swedish pension system consists of three public and two private pillars (Hagen, 2017). The public pillars include the minimum guaranteed pension financed by taxes, the income pension financed by employers and employees, and the premium pensions financed by employees. While the minimum guaranteed pension is a means-tested benefit for individuals with no or low levels of income, the income and premium pensions are defined-contribution schemes, with the premium pension allowing employees to choose where to invest their savings. The private pillars include defined-contribution occupational pensions based on collective-bargaining agreements and tax-deductible private savings. In addition to the guaranteed pension, the occupational pension achieves almost universal coverage (Whitehouse, 2003). On average, the pension replacement rate for individuals currently entering the labor force is $55 \%$ (OECD, 2017) (see Table 1). During the pension system reforms between 1994 and 2003, the mandatory retirement age was abolished and a SEA that differs across pillars was introduced: age 61 for the earnings-related pensions and age 65 for the guaranteed pension. The Swedish pension system allows recipients to combine pension benefits with paid employment between ages 61 and 67 . There are no financial restrictions to this scheme and there is no income testing, which tends to encourage employment in later life (Lindecke, Voss-Dahm, \& Lehndorff, 2007). If retirement is deferred, there are automatic actuarial adjustments. For instance, for a full-career average earner, a deferral of one year leads to a 7\% increase in the annual pension benefit (OECD, 2017).

Second, the Danish pension system consists of a public basic scheme, a means-tested supplementary pension benefit for the most financially disadvantaged, a mandatory occupation 
pension scheme based on lump-sum contributions, and a compulsory occupational pension that covers approximately $90 \%$ of the employed workforce (OECD, 2017). The average replacement rate is comparatively high, at $80 \%(\mathrm{OECD}, 2017)$. The SEA is 65 , but it is possible to defer the public old-age pension for up to ten years (OECD, 2017). Combining employment and pension is possible, but post-retirement earnings are limited to two-thirds of average earnings, above which pension benefits are reduced $(\mathrm{OECD}, 2017)$. An activation program to incite employment among older workers has been introduced in recent decades. However, two types of early retirement programs established in the late 1970s have had an impact among eligible cohorts: a voluntary early retirement pay program that allowed retirement at age 60 and a transitional benefit program that allowed retirement at age 50 or 55 (König \& Schilling, 2016). There is an incremental increase in pension benefits related to retirement deferral; for instance, for a full-career average earner, a deferral of one year leads to a $7 \%$ increase in the annual pension benefit (OECD, 2017).

Third, during a military dictatorship in the early 1980s, Chile replaced a public definedbenefit pay-as-you-go pension scheme with a private mandatory defined-contribution individualretirement-account pension scheme (Madero-Cabib, De-Amesti, \& Herrera, in press). Since then, all workers (except those in the armed forces) must save $10 \%$ of their income for their old-age pension in private for-profit institutions. In a reform during 2008, the non-contributory component of the pension scheme was modified, and both a solidarity basic pension and a supplementary pension for workers with low levels of private savings were introduced. SEA in Chile is 65 for men and 60 for women (OECD, 2017). Early retirement is possible if a worker can demonstrate that $\mathrm{s} /$ he has sufficient pension savings. At the same time, individuals are not required to stop working in order to claim pension benefits (OECD, 2017). However, the results of a recent study (Herrera, Kornfeld, \& Belloni, 2018) show that only 9\% of women and $28 \%$ of men retire before 
the legal age. At 34\%, the income replacement rate is relatively low (OECD, 2017). Deferral of retirement leads to an incremental increase in pensions, with a full-career average earner who defers retirement for one year receiving a 7\% increase in their annual pension benefit (OECD, 2017).

Fourth, the pension system in the U.S. consists of three pillars: public retired-workers benefits, employer-sponsored pensions, and individual savings (Warner, 2016). On average, the replacement rate is $38 \%(\mathrm{OECD}, 2017)$. The mandatory retirement age of 65 was abolished in the late 1970s in the context of a prohibition of age discrimination. Subsequently, implemented policies prohibited any mandatory retirement before age 70, except for a few specific occupations (Warner, 2016). In the 2000s, the eligibility age for a full pension was gradually increased from 65 to 67 . The age of retirement from labor force participation varies more strongly in the U.S. than in most other countries, which has been attributed to increased old-age income support individualization and the resulting tendency among some groups of workers to opt for early retirement (Warner, 2016). For all workers, retirement deferral leads to an incremental increase of $8 \%$ per year, up to age 70 , independent of earnings levels (OECD, 2017).

An overview of the country-specific retirement schemes is provided in Table 1. As shown, the countries are highly similar with respect to their SEA and their accrual rules. In contrast, the net replacement rate varies greatly between $34 \%$ and $86 \%$, with the social-democratic countries having higher replacement rates than the liberal countries.

- Table 1 here -

\section{Research Hypotheses}

Based on the discussion of the literature, in this study we explore two hypotheses, each corresponding to one of the dimensions of interest relating to retirement trajectories. Regarding 
the first dimension, we hypothesize that, on average, FRPs lead to a lower prevalence of early retirement in Chile and the U.S. (liberal countries) and a higher prevalence of early retirement in Sweden and Denmark (social-democratic countries). Regarding the second dimension, we expect that, with FRPs in place, people with adverse health conditions will be more likely to retire early in Sweden and Denmark (social-democratic countries) than in Chile and the U.S. (liberal countries)

\section{Methods}

\section{Data}

To test these hypotheses, we used a harmonized pooled-country dataset based on three surveys on ageing populations: the HRS for the U.S., which has been conducted bi-annually since 1992; the SHARE for Sweden and Denmark, which has been conducted bi-annually since 2004; and the EPS for Chile, which began in 2002 and was conducted five times between 2002 and 2015. The EPS and SHARE were inspired by the HRS and many of their survey questions are formulated in either the same or a similar manner as those in the HRS, making cross-national comparisons possible.

As indicated in Table 2, the specific survey waves used to analyze retirement trajectories between ages 60 and 70 correspond to the temporal structure of the surveys. Given that SHARE began in 2004 and that one of our interests is to examine retirement trajectories during the same chronological period (i.e. the 10-year period from 2004 to 2014/2015), only the HRS and EPS waves measured beginning in 2004 are considered in this study. Furthermore, we did not analyze SHARE's third wave - a retrospective that did not collect panel information; the same applies to the HRS wave that was also performed that year. Therefore, for the study of retirement trajectories, we used five waves from SHARE and the HRS and four waves from the EPS, all performed from 
2004 on.

We used two main criteria to select our research sample. First, individuals had to be aged 60 in the baseline observation year (2004), which corresponded to wave one in SHARE, wave seven in the HRS, and wave two in the EPS. Second, individuals should have no more than one missing value in the variable we used to measure retirement trajectories (i.e. labor force status) across all five waves analyzed from the HRS and SHARE and across all four waves examined from the EPS. About one-quarter of the resulting sample (25.1\%) had one missing value, while the remaining three-quarters had no missing observations. We relied on multivariate imputations by chained equation (MICE) to impute missing values on labor force status, specifically by performing 50 iterative imputations with the predictive mean matching method and considering all variables included in this study. This procedure yielded a study sample of 2,431 individuals.

\section{- Table 2 here -}

\section{Variables}

The main variable for examining retirement trajectories is labor force status, which includes four mutually exclusive statuses: working full-time, for individuals in a full-time job; working part-time, for people who might or might not be retired but are in a part-time job; out of the labor force, indicating unemployed, disabled, and inactive people; and retired, indicating people fully retired from the labor force.

Other important variables considered in this research are as follows. The first is country. The second is welfare regime, which includes 'liberal' for Chile and the U.S. and 'socialdemocratic' for Sweden and Denmark. The third is chronic conditions at age 60, which has two possible indicators, either 0 chronic conditions or 1 or more chronic conditions. To construct this variable, we considered six different chronic conditions: high blood pressure or hypertension, 
diabetes or high blood sugar, cancer or a malignant tumor, stroke or transient ischemic attack, chronic lung disease, and arthritis or rheumatism. The reason we collapse this measure into a binary variable is that we were specifically interested in contrasting those in excellent health at age 60 with the rest of the sample. The information on these conditions was obtained through survey questions indicating whether a medical doctor had ever diagnosed the respondent as having any of the six chronic diseases. The fourth additional variable considered in this research is gender, the fifth is education (primary, secondary, and tertiary), and the sixth is household income at age 60. Household incomes in Sweden, Denmark, and Chile were converted to U.S. dollars according to the 2004 annual average exchange rate (i.e. the baseline observation year). As $17.1 \%$ of participants had a missing value in this variable, we again performed a MICE imputation procedure based on 50 iterative imputations using the predictive mean matching method. Furthermore, given the large differences in household incomes across the countries included in this study, we decided to use quintiles of household income within each country (ranging from 1 to 5, 1 being the lowest quintile and 5 the highest) in order to obtain a cross-national comparable measure. Household income quintile at age 60 was treated as a numeric variable.

\section{Analysis}

To analyze individuals' retirement trajectories, we employed a longitudinal method called sequence analysis (Abbott, 1995). This longitudinal technique first allows us to arrange the individual sequences of labor force statuses experienced from age 60 to age 70 (across five waves in the HRS and SHARE and four waves in the EPS). Then, sequence analysis measures how similar every pair of individual sequences in the sample are, considering for this purpose the types of statuses experienced, the order in which statuses were experienced, and the timing during which they were experienced. For instance, two people may have similar retirement trajectories if both 
work part-time until their mid-60s and then retire, remaining in that status until the end of the observation period. In this example, we observe similar labor force statuses ('part-time work' and 'retirement'), similar status order ('part-time work' followed by 'retirement'), and similar status timing (transition from 'part-time work' to 'retirement' in the mid-60s).

The measure of similarity between individual sequences is summarized in a distance matrix specifying the modifications or 'costs' (in technical terms, substitution and/or insertion/deletion costs) needed to transform one sequence into another; in other words, which are needed for both individual sequences to have the same type, order, and timing of labor force statuses (Abbott, 1995). There are different techniques to measure similarities between individual sequences, including dynamic hamming distances, generalized hamming, and optimal matching analysis. In this study, we use the latter mainly because it considers both substitution and insertion/deletion costs, which is necessary when working with sequences of different lengths (Gabadinho, Ritschard, Mueller, \& Studer, 2011).

Once a distance matrix is built, it can be analyzed using a hierarchical cluster analysis, which gathers similar individual trajectories in different clusters or types. In this way, this technique allows us to group all the diverse retirement pathways experienced by people between ages 60 and 70 in only a few types of similar trajectories. We specifically applied Ward's (1963) hierarchical cluster method. To determine the most robust and informative number of trajectory types (i.e. the number of types that best summarize the diverse retirement pathways), we employed the average silhouette width (ASW) index. This index ranges from zero to one for different numbers of clusters (types), with an index value nearer to one indicating greater robustness (Kaufmann \& Rousseew, 1990).

To test our hypotheses, after creating the types of retirement trajectories, we examined their 
relationships with the other variables of interest (country, welfare regime, chronic conditions at age 60, gender, education, and household income quintile at age 60). We started with descriptive frequency tables and then conducted multinomial logistic regressions, in which retirement trajectory types were used as dependent variables and the rest of the variables served as covariates. In these regression models, we also tested the interaction effects between welfare regimes and chronic conditions at age 60. We used the statistical software R (R Core Team, 2018) in all the analyses. Specifically, we used the TraMineR library (Gabadinho et al., 2011) for the sequence analysis, nnet (Ripley \& Venables, 2016) and effects libraries (Fox \& Hong, 2009) for the multinomial logistic regressions, and the mice library (van Buuren \& Groothuis-Oudshoorn, 2010) for the multivariate imputation by chained equations.

\section{Results}

\section{Retirement Trajectories}

As indicated in Figure 1, four and five types of retirement trajectories yielded the highest ASW values ( 0.39 and 0.37 , respectively) and therefore seemed appropriate in order to summarize the variety of pathways followed by 2,431 individuals between ages 60 and 70 . However, as the four-cluster solution did not provide sufficient information on all key retirement patterns (results available upon request), we decided to work with the five-cluster solution.

- Figure 1 here -

Figure 2 presents the five types of retirement trajectories. The first trajectory $(42.9 \%$, $\mathrm{N}=1,042$ ) is called early retirement. In this type, about half of the people retired in their early $60 \mathrm{~s}$ and almost everyone was fully retired by their mid-60s. The second trajectory $(23.2 \%, \mathrm{~N}=560)$, on-time retirement, is characterized by a very high share of workers who were employed during the first half of their 60 s and retired around the relevant SEA, about age 65. A third type of 
trajectory $(9.8 \%, \mathrm{~N}=239)$, late retirement, is characterized by high levels of full-time employment until individuals are in their late $60 \mathrm{~s}$. In the fourth type of trajectory $(9.6 \%, \mathrm{~N}=233)$, part-time work, $60 \%$ of workers were employed part-time throughout the entire observation period. This trajectory was the least frequently experienced. Finally, the fifth type (14.7\%, N=357), not in the labor market, stands out due to the high share of workers it represents who were not participating in the labor force before retiring. Overall, we find that, in the countries included in this study, early retirement is by far the most frequent trajectory; twice as frequent as on-time retirement and about five times as frequent as late retirement and part-time work. This finding shows that, in countries with FRPs, there is not much incentive to extend working lives.

- Figure 2 here -

\section{Retirement Trajectories According to Different Characteristics}

We show the frequency of the five types of retirement trajectories according to welfare regime, country, chronic conditions at age 60, and socio-demographic characteristics (Table 3). We find that early retirement is a less frequent trajectory in Chile (27.4\%) and the U.S. (47.2\%) and a more frequent trajectory in Sweden (54\%) and Denmark (61.9\%). When we summarize according to the type of welfare regime, we thus see a difference in early retirement between the social-democratic (57.7\%) and liberal (39.7\%) countries included in this study. Unsurprisingly, we find that the share of workers with one or more chronic conditions at age 60 is highest $(71.5 \%)$ in the early retirement trajectory. However, we also find high shares of workers with one or more chronic conditions in the part-time work (65.7\%) and not in the labor market (64.8\%) trajectories. Interestingly, we find the lowest share of workers with one or more chronic conditions in the late retirement trajectory. With respect to gender, we find that, compared to men, women are observed about twice as frequently in the early retirement and part-time work trajectories and about four 
times as frequently in the not in the labor market trajectory. Furthermore, within the early retirement, on-time retirement, and late retirement trajectories, the share of workers with each of the three levels of education are similarly distributed. This contrasts with the patterns in the not in the labor market trajectory, where we find mainly poorly educated workers, and in the part-time work trajectory, where we find mainly highly educated workers. In terms of household income quantile, we observe that the late retirement trajectory has the highest average (3.81), while the not in the labor market trajectory has the lowest (2.77).

The multinomial logistic regression analysis displayed in Table 4 indicates factors associated with the five types of retirement trajectories. The upper part of the table displays results without interaction effects between welfare regimes and chronic conditions at age 60 , while the bottom part displays results that include interaction effects. We use the on-time retirement trajectory as the reference category, as we hoped to observe the impacts of the factors associated with retirement trajectories in relation to retirement at SEA.

As shown in Table 4 (upper part), we observe first that individuals in Sweden and Denmark (social-democratic welfare regime) are significantly more likely to follow the early retirement trajectory and significantly less likely to follow the late retirement and not in the labor market trajectories than individuals in Chile and the U.S. (liberal welfare regime). With respect to gender, we find that women are about 2.5 times more likely to follow the early retirement and part-time work trajectories and seven times more likely to follow the not in the labor market trajectory than men. Individuals with tertiary education are about 2.5 times more likely to follow the part-time work trajectory and are less likely to follow the early retirement trajectory than workers with a primary education. Both people with secondary and tertiary educations are less likely to follow the not in the labor market trajectory than people with a primary education. Individuals with one or 
more chronic conditions at age 60 are about 1.9 times more likely to follow the early retirement trajectory than individuals without any chronic conditions at that age. Finally, people with lower household income are more significantly associated with the early retirement and the not in the labor market trajectories.

The interaction effects between type of welfare regime and chronic conditions at age 60 (bottom part of Table 4) suggest that individuals with one or more chronic conditions are twice (2.04) as likely to follow an early retirement trajectory in Chile and the U.S. In contrast, there is no significant difference between those with or without a chronic condition at age 60 in Sweden and Denmark.

\section{Discussion}

This study examines two dimensions of retirement trajectories between ages 60 and 70 in countries with FRPs but different welfare regimes. First, it explores the link between retirement and welfare regimes and, second, it examines the association between retirement and health conditions in different welfare regimes.

Our analyses show that early retirement trajectories are the most prevalent across countries. The second-most prevalent are on-time retirement trajectories. Together, these cover about twothirds of the individuals included in this study. This result is in line with an earlier study based on nine OECD countries with FRPs that found a widespread and sudden decline in labor force participation at and even before the statutory retirement age (Börsch-Supan et al., 2017). Similarly, a study of 14 European countries showed that policies allowing part-time work at the end of an occupational career did not encourage the prolongation of working life (Hess, Bauknecht, \& Pink, 2018). Thus, the trend of moving away from early retirement schemes toward flexible retirement schemes does not necessarily lead individuals to retire later. The persistency of early retirement 
as the most prevalent path may be due to its perception as a social right (Ebbinghaus \& Hofäcker, 2013), while on-time retirement's position as the second-most prevalent trajectory may be explained by individuals adjusting their retirement timing to social norms concerning the ideal retirement age (Radl, 2013).

Overall, these findings indicate that the goal of FRPs to encourage workers to extend their working lives has not been met in the countries under study. However, there exist differences with respect to both the country and the welfare regime, as individuals in Chile and the U.S. are less likely to retire early and more likely to retire late compared to individuals in Sweden and Denmark. We thus find support for our first hypothesis, which states that early retirement is less prevalent in Chile and the U.S. (liberal countries) than in Sweden and Denmark (social-democratic countries). This finding cannot be explained by the financial incentives for deferral of retirement that are provided in the four countries under study, since all countries provide an incremental increase in pensions of about the same scope (7-8\%) for each year of retirement deferral. An alternative explanation has been provided by previous policy research, arguing that more generous early retirement schemes encourage workers to retire before SEA (Ebbinghaus, 2006). This argument is supported by the particularly high share of early retirement trajectories in Denmark, where a voluntary early retirement program that is associated with unemployment insurance may incite early labor force exits (OECD, 2017), and by the particularly low share of early retirement trajectories in Chile, where workers may be forced to work longer due to a large informal labor sector.

Our research complements previous results by using a trajectory approach that allows us not only to focus on retirement timing in countries with FRPs but also to provide a fine-grained analysis of the retirement transition unfolding over a period of ten years. Moreover, by considering 
a variety of labor force statuses to describe five distinct retirement trajectories in the years leading up to and beyond SEA, we offer a better understanding of retirement transition patterns in the context of a trend that is moving away from 'conventional retirement transitions' toward an increasing de-standardization of labor force participation in late life.

With respect to the interaction between health conditions and the welfare regime, we find that individuals with chronic conditions are only more likely to retire early if they live in Chile or the U.S. (liberal countries). We therefore do not find support for our second hypothesis, which states that people with adverse health conditions will be more likely to retire early in Sweden and Denmark (social-democratic countries) than in Chile and the U.S. (liberal countries). This finding may be explained by more successful labor market integration of individuals with chronic conditions or disabilities in Sweden and Denmark. In fact, comparative studies find employment rates of disabled workers to be relatively high in Nordic countries. In the U.S. or the United Kingdom, disabled workers are more often unemployed or experience other forms of labor force exclusion (Holland et al., 2011; Parker Harris, Owen, \& Gould, 2012). This phenomenon may be explained on the one hand by differences in the share of individuals receiving disability benefitswhich is higher in the U.S. than in Sweden and Denmark - and on the other hand by public spending on disability and illness cash benefits, vocational rehabilitation, and employment programs, which is substantially higher in Sweden and Denmark than in the U.S. and Chile (see Table 1).

Our results seem to indicate that, in the four countries with FRPs under study, the institutional arrangement of the welfare regime is a stronger factor inciting retirement behavior than individuals' health conditions. Our analysis therefore extends the previous literature identifying ill health as one of the main determinants of early retirement (Jokela et al., 2010; Radl, 
2013). One relevant policy implication of our findings is that adverse health conditions do not necessarily constitute a barrier to labor force participation in late life. In contrast, such participation depends foremost on the broader institutional context, which may promote or hinder the employment of workers with adverse health conditions.

One of our main findings is that, in countries with FRPs, most workers retire early or ontime and do not prolong their working life beyond SEA. The strong assumption of FRPs that individuals will generally be in good health after SEA and willing to continue working therefore receives little support. A possible interpretation of this finding is that there exists large heterogeneity among older workers with respect to their health conditions and desire to continue working - for instance, by gender (Madero-Cabib, Corna, \& Baumann, 2019; van der Horst, Lain, Madero-Cabib, Calvo, \& Vickerstaff, 2017; Worts, Corna, Sacker, McMunn, \& McDonough, 2016). In fact, we find that women more frequently experience not in the labor market or parttime trajectories than men. At the same time, late retirement trajectories are substantially more frequent among men than among women. These gender-segregated patterns may be shaped by gendered social norms with respect to employment. Heterogeneity in the trajectories is also observed by education, individuals with tertiary education being substantially more likely to work part-time at the end of their careers than individuals with lower levels of education. This pattern may be explained by the better working conditions that more educated individuals tend to experience across their careers (Kauhanen \& Nätti, 2014).

\section{Policy implications}

This implies that policymakers must better address individuals' heterogenous situations. If FRPs should incite individuals to work longer, they have to take individuals' needs into account. For instance, policies could be implemented that not only allow older workers to work part-time at the 
end of their career but that also actively provide them with support in this endeavor. More concretely, rights could be implemented that would allow older workers to reduce their working hours and have access to workplace adjustment measures. An integration of mechanisms that determine how companies and organizations deal with older workers would likely contribute to the success of such policies.

\section{Limitations}

The main between-country differences we consider are the features of the policies on retirement, old-age pensions, and disability. Therefore, in this study, we omit other welfare institutions that are potentially relevant to retirement transitions, such as the health care system and family models. Moreover, our study examines FRPs based on only four countries. We therefore cannot generalize our results to all countries with FRPs.

\section{Future research directions}

Future research may expand the analysis to other countries with FRPs in order to gain a better understanding of the mechanisms driving retirement trajectories. Another direction of future research would be to examine whether younger cohorts adjust differently to the reforms of old-age pension policies. Classical life course studies have demonstrated that studying cohort changes can be a powerful tool for understanding social changes (Giele \& Elder, 1998; Ryder, 1965) and this approach may reveal whether cohort-specific aspects, such as post-war working conditions, were major influences on our results.

\section{Conclusion}

Our study contributes to the policy literature focused on the effect of flexible retirement policies on working life extension. Using a trajectory approach, we find that the majority of individuals living in four countries with FRPs follow early retirement and on-time retirement 
pathways. The share of individuals in early retirement trajectories is higher in Sweden and Denmark (social-democratic countries) than in Chile and the U.S. (liberal countries); interestingly, individuals with chronic conditions are only more likely to follow this trajectory in Chile and the U.S. (liberal countries). Therefore, while our results do not provide evidence that flexible retirement policies promote the extension of working life beyond statutory retirement ages, we observe that both welfare regime and individual health conditions play moderating roles.

\section{Funding}

This work was supported by the Swiss National Science Foundation under Grant number 179696, CONICYT/FONDECYT/INICIACION/N¹1180360, CONICYT/FONDAP/N 15130009 , Millennium Science Initiative of the Ministry of Economy Development and Tourism, Chile, Grant "Millennium Nucleus for the Study of the Life Course and Vulnerability (MLIV)".

\section{Disclosure Statement}

No potential conflict of interest was reported by the authors.

\section{Data Availability Statement}

The data that support the findings of this study are openly available: $\underline{\text { HRS }}, \underline{\text { SHARE}}, \underline{\text { ELSA }}$ EPS

\section{Contact details}

\section{Isabel Baumann}

-Institute of Health Sciences, School of Health Professions, Zurich University of Applied Sciences, Switzerland

-National Centre of Competence in Research "Overcoming Vulnerability: Life Course Perspectives" 
-Centre for the Interdisciplinary Study of Gerontology and Vulnerability, University of Geneva Technikumstrasse 81

8400 Winterthur

Switzerland

ORCID: 0000-0002-8813-9722

\section{Ignacio Madero-Cabib (corresponding author)}

-Institute of Sociology \& Public Health Department, Pontificia Universidad Católica de Chile, Santiago, Chile.

-Millennium Nucleus for the Study of the Life Course and Vulnerability (MLIV), Chile.

Avenida Vicuna Mackenna 4860

Casilla 306, Correo 22, Macul

Santiago, Chile

i.maderocabib@uc.cl

ORCID: 0000-0002-9918-8562 


\section{References}

Abbott, A. (1995). Sequence Analysis: New Methods for Old Ideas. Annual Review of Sociology, 21(1995), 93-113.

Baumann, I. (2016). The Plight of Older Workers. Labor market experience after plant closure in the Swiss manufacturing sector. Cham: Springer.

Börsch-Supan, A., Bucher-Koenen, T., Kutlu-Koc, V., \& Goll, N. (2018). Dangerous flexibility Retirement reforms reconsidered. Economic Policy, 33(94), 317-355. https://doi.org/10.1093/epolic/eiy002

Calvo, E., Madero-Cabib, I., \& Staudinger, U. M. (2018). Retirement sequences of older Americans: Moderately destandardized and highly stratified across gender, class, and race. The Gerontologist, 58(6), 1166-1176. https://doi.org/10.1093/geront/gnx052

Charles, K. K., \& Decicca, P. (2007). Hours flexibility and retirement. Economic Inquiry, 45(2), 251-267. https://doi.org/10.1111/j.1465-7295.2006.00009.x

Diaz-Toro, F., Madero-Cabib, I., Calvo, E., \& Staudinger, U. M. (2018). Heartbreaking Careers in Old Age: Retirement Sequences as a Non-Traditional Risk Factor for Cardiovascular Diseases. Circulation, 137 (Suppl, A020.

Duberley, J., \& Carmichael, F. (2016). Career Pathways into Retirement in the UK: Linking Older Women's Pasts to the Present. Gender, Work and Organization, 23(6), 582-599. https://doi.org/10.1111/gwao.12144

Ebbinghaus, B. (2006). Reforming Early Retirement in Europe, Japan and the USA. In Reforming Early Retirement in Europe, Japan and the USA. https://doi.org/10.1093/0199286116.001.0001

Ebbinghaus, B., \& Hofäcker, D. (2013). Reversing early retirement in advanced welfare 
economies: Overcoming push and pull factors. Comparative Population Studies, 38(4), 807-840. https://doi.org/10.12765/CPoS-2013-24en

Esping-Andersen, G. (1990). The Three Worlds of Welfare Capitalism. Cambridge, UK: Polity Press.

Eurofound. (2016). Extending working lives through flexible retirement schemes: partial requirement. https://doi.org/10.2806/004233

Fox, J., \& Hong, J. (2009). Effect displays in R for Multinomial and Proportional-Odds Logit Models: extensions to the effects package. Journal of Statistical Software, 32(1), 1-24. https://doi.org/10.18637/jss.v032.i01

Fritzell, J., \& Lundberg, O. (2007). Health inequalities and welfare resources: Continuity and change in Sweden. Bristol, UK: Policy Press.

Gabadinho, A., Ritschard, G., Mueller, N. S., \& Studer, M. (2011). Analyzing and Visualizing State Sequences in R with TraMineR. Journal of Statistical Software, 40(4), 1-37. Retrieved from http://archive-ouverte.unige.ch/unige:16809?gathStatIcon=true

Gallie, D., \& Paugam, S. (2000). The Experience of Unemployment in Europe: The Debate. In D. Gallie \& S. Paugam (Eds.), Welfare regimes and the experience of unemployment in Europe (Oxford Uni, pp. 1-22). Oxford.

Giele, J. Z., \& Elder, G. H. J. (1998). Methods of Life Course Research: Qualitative and Quantitative Approaches (J. Z. Giele \& G. H. J. Elder, eds.). https://doi.org/10.2307/3089377

Hagen, J. (2017). Pension principles in the Swedish pension system. Scandinavian Economic History Review, 65(1), 28-51. https://doi.org/10.1080/03585522.2016.1269670

Herrera, M.-S., Kornfeld, R., \& Belloni, C.-L. (2018). Trabajo y personas mayores en Chile: 
Lineamientos para una politica de inclusión laboral Estudio nacional en personas entre 55 y 74 años. Santiago: Pontificia Universidad Católica de Chile.

Hess, M., Bauknecht, J., \& Pink, S. (2018). Working Hours Flexibility and Timing of Retirement: Findings from Europe. Journal of Aging and Social Policy, 30(5), 478-494. https://doi.org/10.1080/08959420.2018.1500857

Hofäcker, D., Hess, M., \& König, S. (2016). Delaying retirement: Progress and challenges of active aging in Europe, the United States and Japan. London: Palgrave Macmillan.

Holland, P., Nylén, L., Thielen, K., Wel, K. A. van der, Chen, W.-H., Barr, B., ... Whitehead, M. (2011). How Do Macro-Level Contexts and Policies Affect the Employment Chances of Chronically Ill and Disabled People? Part II: The Impact of Active and Passive Labor Market Policies. International Journal of Health Services, 41(3), 415-430. https://doi.org/https://doi.org/10.2190/HS.41.3.b

Johnson, R. W. (2011). Phased Retirement and Workplace Flexibility for Older Adults: Opportunities and Challenges. Annals of the American Academy of Political and Social Science, 638(1), 68-85. https://doi.org/10.1177/0002716211413542

Jokela, M., Head, J., Vahtera, J., Westerlund, H., \& Marmot, M. G. (2010). From midlife to early old age: Health trajectories associated with retirement. Epidemiology, 21(3), 284-290. https://doi.org/10.1097/EDE.0b013e3181d61f53.From

Kaufmann, L., \& Rousseew, P. J. (1990). Finding Groups in Data. An Introduction to Cluster Analysis. Hoboken, JK: John Wiley \& Sons, Ltd.

Kauhanen, M., \& Nätti, J. (2014). Involuntary Temporary and Part-Time Work, Job Quality and Well-Being at Work. Social Indicators Research, 120(3), 783-799. https://doi.org/10.1007/s11205-014-0617-7 
König, S., \& Schilling, J. (2016). The Outdistanced Vanguard: Early Retirement Policy in Denmark as an Obstacle to Progress in Active Aging. In Delaying retirement: Progress and challenges of active aging in Europe, the United States and Japan (pp. 291-314). London: Palgrave Macmillan.

Lindecke, C., Voss-Dahm, D., \& Lehndorff, S. (2007). Altersteilzeit: Erfahrungen und Diskussionen in Deutschland und anderen EU-Ländern (No. 142).

Madero-Cabib, I., De-Amesti, J., \& Herrera, M.-S. (n.d.). The gendered ageing context in Chile. In A. Ní Léime, J. Ogg, D. Street, I. Madero-Cabib, C. Krekula, M. Rasticova, \& M. Bediova (Eds.), Extended Working Life Policies. International Gender and Health Perspective. The Netherlands: Springer.

Madero-Cabib, Ignacio, Corna, L. M., \& Baumann, I. (2019). Aging in different welfare contexts: A comparative perspective on later-life employment and health. Journals of Gerontology: Social Sciences. https://doi.org/https://doi.org/10.1093/geronb/gbz037

OECD. (2010). Sickness, Disability and Work: Breaking the Barriers. Paris: OECD Publishing.

OECD. (2017a). Chile. In Pensions at a Glance 2017. Paris: OECD Publishing.

OECD. (2017b). Denmark. In Pensions at a Glance 2017. https://doi.org/10.1787/888933636054

OECD. (2017c). Pensions at a Glance 2017. https://doi.org/10.1787/pension_glance-2013-en

OECD. (2018). United States: Working better with age and fighting unequal ageing. Paris: OECD Publishing.

Parker Harris, S., Owen, R., \& Gould, R. (2012). Parity of participation in liberal welfare states: Human rights, neoliberalism, disability and employment. Disability and Society, 27(6), 823-836. https://doi.org/10.1080/09687599.2012.679022

Platts, L. G., Corna, L. M., Worts, D., McDonough, P., Price, D., \& Glaser, K. (2019). Returns to 
work after retirement: a prospective study of unretirement in the United Kingdom. Ageing \& Society, 39, 439-464. https://doi.org/10.1017/S0144686X17000885

R Core Team. (2018). $R$ : A langugage and environment for statistical computing. Vienna.

Radl, J. (2013). Labour market exit and social stratification in Western Europe: The effects of social class and gender on the timing of retirement. In European Sociological Review (Vol. 29). https://doi.org/10.1093/esr/jcs045

Ripley, B., \& Venables, W. (2016). Package 'nnet.'

Ryder, N. B. (1965). The Cohort as a Concept in the Study of Social Change. American Sociological Review, 30(6), 843-861. https://doi.org/10.2307/2090964

Schofield, D. J., Callander, E. J., Kelly, S. J., \& Shrestha, R. N. (2017). Working beyond the traditional retirement age: The influence of health on Australia's older workers. Journal of Aging and Social Policy, 29(3), 235-244. https://doi.org/10.1080/08959420.2016.1246319

Shuey, K. M., \& O’Rand, A. M. (2004). New risks for workers: Pensions, labor markets, and gender. Annual Review Sociology, 30, 453-477. https://doi.org/10.1146/annurev.soc.30.012703.110534

Spini, D., Bernardi, L., \& Oris, M. (2017). Vulnerability Across the Life Course. Research in Human Development, 14(1), 1-4. https://doi.org/10.1080/15427609.2016.1268891

van Buuren, S., \& Groothuis-Oudshoorn, K. (2010). MICE : Multivariate Imputation by Chained Equations in R. Journal of Statistical Software, 45(3), 1-68. https://doi.org/10.18637/jss.v045.i03

van der Horst, M., Lain, D., Madero-Cabib, I., Calvo, E., \& Vickerstaff, S. (2017). Gendered late careers in the United States and The United Kingdom: A Sequence Analysis. Innovation in Aging, Suppl_1, 678-679. 
Wahrendorf, M., Zaninotto, P., Hoven, H., Head, J., \& Carr, E. (2017). Late Life Employment Histories and Their Association With Work and Family Formation During Adulthood: A Sequence Analysis Based on ELSA. The Journals of Gerontology: Series B, 73(7), $1263-$ 1277. https://doi.org/10.1093/geronb/gbx066

Ward, J. H. J. (1963). Hierarchical grouping to optimize an objective function. The Journal of the American Statistical Association, 58(301), 236-244.

Warner, D. F. (2016). The Increasing Heterogeneity of Retirement in the USA: Interactions Between State, Firm, and Individual Determinants of Later-Life Labor Force Withdrawal. In Delaying Retirement: Progress and Challenges of Active Aging in Europe, the United States and Japan (pp. 337-362). London: Palgrave Macmillan.

Warner, D. F., Hayward, M. D., \& Hardy, M. A. (2010). The retirement life course in America at the dawn of the twenty-first century. Population Research and Policy Review, 29(6), 893919. https://doi.org/10.1007/s11113-009-9173-2

Whitehouse, E. (2003). The value of pension entitlements: A model of nine OECD countries (No. 9). Paris.

Worts, D., Corna, L., Sacker, A., McMunn, A., \& McDonough, P. (2016). Understanding older adults' labour market trajectories: a comparative gendered life course perspective. Longitudinal and Life Course Studies, 7(4), 347-367. https://doi.org/10.14301/1lcs.v7i4.389 


\section{Appendix}

Table 1. Overview of retirement schemes of the four countries studied

\begin{tabular}{|c|c|c|c|c|c|c|}
\hline Country & $\begin{array}{l}\text { Welfare } \\
\text { regime }\end{array}$ & $\begin{array}{l}\text { Statutory } \\
\text { eligibility } \\
\text { age (SEA) }\end{array}$ & $\begin{array}{l}\text { Net } \\
\text { replace } \\
\text { ment } \\
\text { rate }^{1}\end{array}$ & Flexibility rules & Benefit offset and accrual rules ${ }^{2}$ & $\begin{array}{c}\text { Polices for disabled } \\
\text { workers }{ }^{3}\end{array}$ \\
\hline Sweden & $\begin{array}{c}\text { Social- } \\
\text { democratic }\end{array}$ & $\begin{array}{c}65 \text { for } \\
\text { guaranteed } \\
\text { pension; } \\
61 \text { for earning- } \\
\text { related } \\
\text { pensions }\end{array}$ & $56 \%$ & $\begin{array}{l}\text { There is no fixed retirement age, } \\
\text { only pension eligibility ages. } \\
\text { Receipt of pension can be } \\
\text { deferred with no upper age limit. } \\
\text { It is also possible to combine } \\
\text { work and pension receipt. } \\
\text { Pensions can be partially } \\
\text { withdrawn. }\end{array}$ & $\begin{array}{l}\text { If retirement is deferred beyond SEA, } \\
\text { there are automatic actuarial } \\
\text { adjustments for notional accounts and } \\
\text { premium pensions (but not for } \\
\text { guaranteed pensions and occupational } \\
\text { pensions). For instance, for a full- } \\
\text { career average earner, a deferral of one } \\
\text { year leads to an increase of the annual } \\
\text { pension benefit by } 7 \% \text {. The accrual } \\
\text { rates do not vary with earnings in the } \\
\text { public pension scheme but do in the } \\
\text { occupational pension scheme. The } \\
\text { occupational plans pay a higher } \\
\text { replacement rate to high earners on } \\
\text { their pay above the ceiling of the } \\
\text { public plan. }\end{array}$ & $\begin{array}{l}\text { The share of individuals } \\
\text { who receive disability } \\
\text { benefits is } 26 \% \text {. The } \\
\text { public expenditure on } \\
\text { disability and illness } \\
\text { cash benefits is } 2 \% \text { of } \\
\text { GDP. The share of total } \\
\text { disability-related } \\
\text { spending on vocational } \\
\text { rehabilitation and } \\
\text { employment programs } \\
\text { of social spending on } \\
\text { incapacity benefits (of } \\
\text { GDP) is } 9 \%(0.4 \% \text { ). }\end{array}$ \\
\hline Denmark & $\begin{array}{c}\text { Social- } \\
\text { democratic }\end{array}$ & 65 & $86 \%$ & $\begin{array}{l}\text { Public old-age pension can be } \\
\text { deferred for up to ten years. } \\
\text { Combining pensions and } \\
\text { employment is possible. }\end{array}$ & $\begin{array}{l}\text { The increment for each year of deferral } \\
\text { is the ratio of the period of deferral } \\
\text { (e.g., one year) to the average life } \\
\text { expectancy at the time of the pension } \\
\text { (e.g., } 17 \text { years) }(1 / 17=5.8 \% \text { ). In an } \\
\text { example calculation for a full-career } \\
\text { average earner, the OECD ( } 2017 \text { ) } \\
\text { reports that a deferral of one year leads }\end{array}$ & $\begin{array}{l}\text { The share of individuals } \\
\text { who receive disability } \\
\text { benefits is } 24 \% \text {. The } \\
\text { public expenditure on } \\
\text { disability and illness } \\
\text { cash benefits is } 3 \% \text { of } \\
\text { GDP. The share of total } \\
\text { disability-related }\end{array}$ \\
\hline
\end{tabular}




\begin{tabular}{|c|c|c|c|c|c|c|}
\hline & & & & & $\begin{array}{l}\text { to a } 7 \% \text { increase in the annual pension } \\
\text { benefit. For pension beneficiaries who } \\
\text { are involved in paid employment, } \\
\text { pension benefits are reduced above a } \\
\text { certain level of post-retirement } \\
\text { earnings (two-thirds of average } \\
\text { earnings). The accrual rates do not } \\
\text { vary with earnings. }\end{array}$ & $\begin{array}{l}\text { spending on vocational } \\
\text { rehabilitation and } \\
\text { employment programs } \\
\text { of social spending on } \\
\text { incapacity benefits (of } \\
\text { GDP) is } 16 \%(0.7 \%) \text {. }\end{array}$ \\
\hline Chile & Liberal & $\begin{array}{l}65 \text { for men; } \\
60 \text { for women }\end{array}$ & $34 \%$ & $\begin{array}{l}\text { Early retirement is allowed at } \\
\text { any age if accumulated savings } \\
\text { are sufficient to finance a } \\
\text { pension above certain } \\
\text { thresholds. At the same time, it } \\
\text { is possible to defer pension } \\
\text { claims until after SEA; pension } \\
\text { benefits can be withdrawn at any } \\
\text { point from that age forward. } \\
\text { Individuals are not required to } \\
\text { stop working to claim a pension } \\
\text { benefit. }\end{array}$ & $\begin{array}{l}\text { Upon retirement, individuals can } \\
\text { choose between four pay-out options: } \\
\text { immediate life annuity; temporary } \\
\text { income with a deferred life annuity; } \\
\text { programmed withdrawal; and a split } \\
\text { between an immediate life annuity and } \\
\text { a programmed withdrawal. If } \\
\text { individuals defer pension claims until } \\
\text { after SEA, a deferral of one year leads } \\
\text { to a } 7 \% \text { increase in the annual pension } \\
\text { benefit for a full-career average earner. } \\
\text { The accrual rates do not vary with } \\
\text { earnings. }\end{array}$ & $\begin{array}{l}\text { The public expenditure } \\
\text { on disability and illness } \\
\text { cash benefits is } 0.7 \% \text { of } \\
\text { GDP. The other } \\
\text { indicators are not } \\
\text { available for Chile. }\end{array}$ \\
\hline $\begin{array}{l}\text { United } \\
\text { States }\end{array}$ & Liberal & 67 & $38 \%$ & $\begin{array}{l}\text { Early retirement is possible from } \\
\text { age } 62 . \text { Receipt of the pension } \\
\text { can be deferred beyond SEA. } \\
\text { Moreover, it is possible to } \\
\text { combine work and pension } \\
\text { receipt subject to an earnings } \\
\text { test. }\end{array}$ & $\begin{array}{l}\text { Early retirement is subject to an } \\
\text { actuarial reduction of about } 7 \% \text { for } \\
\text { each year of retirement before the } \\
\text { SEA. However, after three years, the } \\
\text { reduction falls to } 5 \% \text {. Deferral of } \\
\text { retirement leads to an incremental } \\
\text { increase of } 8 \% \text { per year of deferral up } \\
\text { to age } 70 \text {. If pension beneficiaries are } \\
\text { employed but are below statutory } \\
\text { retirement age, they are subject to a } \\
50 \% \text { reduction if earnings exceed }\end{array}$ & $\begin{array}{l}\text { The share of individuals } \\
\text { who receive disability } \\
\text { benefits is } 48 \% \text {. The } \\
\text { public expenditure on } \\
\text { disability and illness } \\
\text { cash benefits is } 1.4 \% \text { of } \\
\text { GDP. The share of total } \\
\text { disability-related } \\
\text { spending on vocational } \\
\text { rehabilitation and } \\
\text { employment programs }\end{array}$ \\
\hline
\end{tabular}


Sources: OECD, 2010, 2017c

${ }^{1}$ The net replacement rate is the gross pension entitlement divided by net pre-retirement earnings $(\mathrm{OECD}, 2017)$. We indicate the net replacement rate for earners at retirement age.

${ }^{2}$ The benefit offset and accrual rules provide information about the actuarial neutrality of pension schemes. An actuarially neutral pension scheme ensures that at a given age (close to the retirement age) a worker is financially neutral ('indifferent') from an actuarial perspective between retiring and working an extra year. The accrual rate shows the increment at which benefit entitlements build up for each year of coverage.

${ }^{3}$ Source: OECD (2010.59): Table 2.8 
Table 2. Survey waves used to analyze retirement trajectories

\begin{tabular}{c|ccc|c}
\hline Year & \multicolumn{3}{|c|}{ Survey waves } & Age \\
& SHARE & HRS & EPS & \\
\hline 2004 & 1 & 7 & 2 & 60 \\
2005 & 2 & 8 & 3 & \\
2006 & 3 & 9 & & \\
2007 & 4 & 10 & 4 & $\sim 65$ \\
2008 & 5 & 11 & & \\
2009 & & & & \\
2010 & 6 & 12 & & \\
2011 & & & 5 & \\
2012 & & & & \\
2013 & & & & \\
2014 & & & & \\
\hline
\end{tabular}

Note: Waves not considered in analyses highlighted in grey. 
Table 3. Retirement trajectories by welfare regime and socio-demographic characteristics (\%)

\begin{tabular}{lccccc}
\hline & $\begin{array}{c}\text { Early } \\
\text { retirement }\end{array}$ & $\begin{array}{c}\text { On-time } \\
\text { retirement }\end{array}$ & $\begin{array}{c}\text { Late } \\
\text { retirement }\end{array}$ & $\begin{array}{c}\text { Part-time } \\
\text { work }\end{array}$ & $\begin{array}{c}\text { Not in the } \\
\text { labor market }\end{array}$ \\
\hline$\%$ & 42.9 & 23.2 & 9.8 & 9.6 & 14.7 \\
$\mathrm{~N}$ & 1042 & 560 & 239 & 233 & 357 \\
\hline Country (\% row) & & & & & \\
$\quad$ Sweden & 54.0 & 35.4 & 1.3 & 8.4 & 0.9 \\
$\quad \begin{array}{l}\text { Denmark } \\
\text { United States }\end{array}$ & 61.9 & 21.2 & 3.0 & 9.6 & 4.1 \\
$\quad$ Chile & 47.2 & 18.2 & 12.0 & 14.8 & 8.8 \\
Welfare regime (\% row) & 27.4 & 27.8 & 10.5 & 3.0 & 31.2 \\
$\quad$ Social-democratic & 57.7 & 28.8 & 2.1 & 9.0 & 2.4 \\
$\quad$ Liberal & 39.7 & 21.8 & 11.5 & 9.7 & 17.3 \\
Chronic conditions & & & & & \\
$\quad$ at age 60 (\% column) & & & & & \\
$\quad$ None & 28.5 & 44.6 & 35.2 & 34.3 & 47.2 \\
$\quad$ One or more & 71.5 & 55.4 & 52.8 & 65.7 & 64.8 \\
Gender (\% column) & & & & & \\
$\quad$ Women & 63.8 & 38.8 & 38.1 & 61.4 & 79.8 \\
$\quad$ Men & 36.2 & 61.2 & 61.9 & 38.6 & 20.2 \\
Education (\% column) & & & & & \\
$\quad \begin{array}{l}\text { Primary } \\
\text { Secondary }\end{array}$ & 31.0 & 30.9 & 28.0 & 17.2 & 60.5 \\
$\quad$ Tertiary & 44.5 & 38.0 & 42.3 & 39.1 & 33.1 \\
Household income & 24.5 & 31.1 & 39.7 & 43.8 & 6.4 \\
quantile at age 60 (mean & $3.23[1.38]$ & $3.74[1.28]$ & $3.81[1.25]$ & $3.74[1.34]$ & $2.77[1.47]$ \\
[standard deviation]) & & & & & \\
\hline
\end{tabular}


Table 4. Multinomial logistic regression analysis (odds ratios)

\begin{tabular}{|c|c|c|c|c|}
\hline $\begin{array}{l}\text { Dependent variable } \\
\text { (Ref: On-time retirement) }\end{array}$ & $\begin{array}{l}\text { Early } \\
\text { retirement }\end{array}$ & $\begin{array}{l}\text { Late } \\
\text { retirement }\end{array}$ & $\begin{array}{l}\text { Part-time } \\
\text { work }\end{array}$ & $\begin{array}{l}\text { Not in the } \\
\text { labor market }\end{array}$ \\
\hline \multicolumn{5}{|c|}{ Regression model with no interaction effects } \\
\hline $\begin{array}{l}\text { Welfare regime (Ref: Liberal) } \\
\text { Social-democratic }\end{array}$ & $1.38^{* *}(0.15)$ & $0.13^{* * *}(0.40)$ & $0.75(0.24)$ & $0.12^{* * *}(0.37)$ \\
\hline Chronic conditions at age 60 (Ref: No & & & & \\
\hline $\begin{array}{c}\text { One or more } \\
\text { Gender (Ref: Men) }\end{array}$ & $1.90^{* * *}(0.12)$ & $0.78(0.16)$ & $1.30(0.18)$ & $0.99(0.16)$ \\
\hline $\begin{array}{l}\text { Women } \\
\text { Education (Ref. Prin }\end{array}$ & $2.51^{* * *}(0.12)$ & $1.06(0.17)$ & $2.49^{* * *}(0.17)$ & $7.33^{* * *}(0.17)$ \\
\hline $\begin{array}{l}\text { Education (Ret: } \\
\text { Secondary }\end{array}$ & $1.27^{*}(0.14)$ & $1.09(0.20)$ & $1.72^{* *}(0.23)$ & $0.42^{* * * *}(0.18)$ \\
\hline Tertiary & $1.05(0.15)$ & $1.05(0.23)$ & $2.82^{* * *}(0.25)$ & $0.15^{* * *}(0.28)$ \\
\hline Household income quantile at age 60 & $0.77^{* * *}(0.05)$ & $1.10(0.07)$ & $0.91(0.07)$ & $0.75^{* * *}(0.06)$ \\
\hline $\begin{array}{l}\text { Constant } \\
\text { Akaike Information Criteria }\end{array}$ & $\begin{array}{c}1.53^{* *}(0.19) \\
5,864 \\
\end{array}$ & $\begin{array}{c}0.40^{* * *}(0.27) \\
5,864 \\
\end{array}$ & $\begin{array}{c}0.19^{* * *}(0.30) \\
5,864 \\
\end{array}$ & $\begin{array}{c}1.15(0.23) \\
5,864 \\
\end{array}$ \\
\hline \multicolumn{5}{|l|}{ Regression model with interaction effects } \\
\hline $\begin{array}{l}\text { Welfare regime (Ref: Liberal) } \\
\quad \text { Social-democratic } \\
\text { Chronic conditions at age } 60 \text { (Ref: No }\end{array}$ & $1.64^{* *}(0.21)$ & $0.19^{* * *}(0.45)$ & $0.84(0.32)$ & $0.11^{* * *}(0.50)$ \\
\hline One or more & $2.04^{* * *}(0.14)$ & $0.83(0.17)$ & $1.36(0.19)$ & $1.02(0.17)$ \\
\hline $\begin{array}{l}\text { Gender (Ref: Men) } \\
\text { Women }\end{array}$ & $2.48^{* * *}(0.12)$ & $1.04(0.17)$ & $2.46^{* * *}(0.17)$ & $7.30^{* * *}(0.17)$ \\
\hline Education (Ref: Primary) & & & & \\
\hline $\begin{array}{l}\text { Secondary } \\
\text { Tertiary }\end{array}$ & $\begin{array}{l}1.27^{*}(0.14) \\
1.04(0.17)\end{array}$ & $\begin{array}{l}1.09(0.20) \\
1.05(0.23)\end{array}$ & $\begin{array}{l}1.72^{* *}(0.23) \\
2.82^{* * *}(0.25)\end{array}$ & $\begin{array}{l}0.41^{* * *}(0.18) \\
0.15^{* * *}(0.28)\end{array}$ \\
\hline Household income quantile at age 60 & $0.77^{* * *}(0.05)$ & $1.10(0.07)$ & $0.91(0.07)$ & $0.75^{* * *}(0.06)$ \\
\hline $\begin{array}{l}\text { Type of regime* } \\
\text { Chronic conditions at age } 60\end{array}$ & & & & \\
\hline Social-democratic* One or more & $0.70(0.30)$ & $0.26(1.12)$ & $0.77(0.47)$ & $1.34(0.74)$ \\
\hline Constant & $1.47^{* *}(0.19)$ & $0.39^{* * *}(0.27)$ & $0.19^{* * *}(0.30)$ & $1.13(0.23)$ \\
\hline Akaike Information Criteria & 5,869 & 5,869 & 5,869 & 5,869 \\
\hline
\end{tabular}

Note: The coefficients indicated are odds ratios. ${ }^{*} \mathrm{p}<0.1,{ }^{* *} \mathrm{p}<0.05,{ }^{* * *} \mathrm{p}<0.01$. Standard deviations in parenthesis. 


\section{Figures}

Figure 1. Average silhouette width index

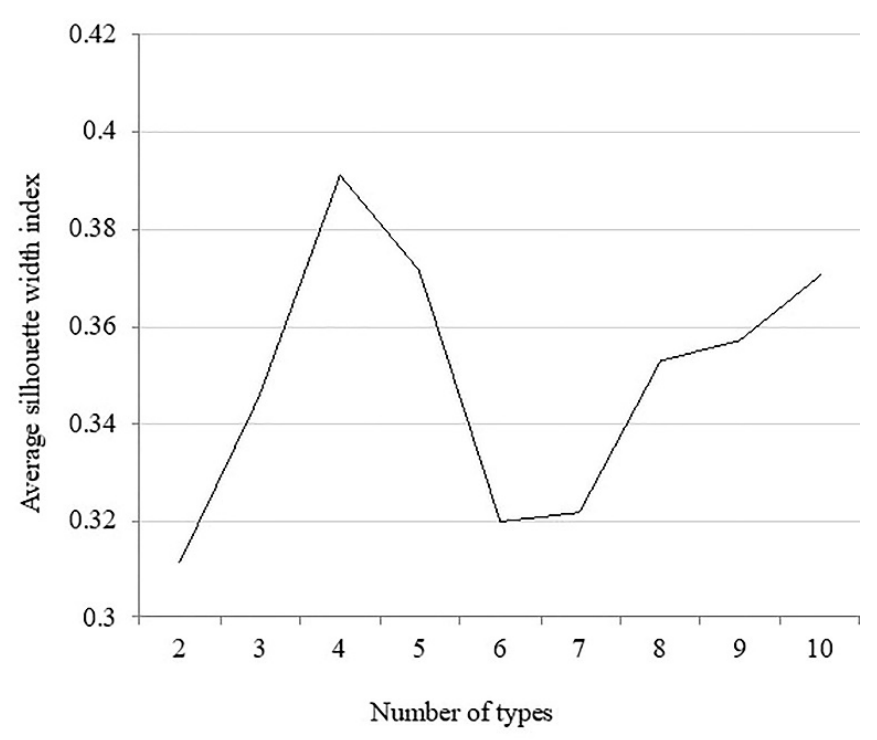

Figure 2. Five types of retirement trajectories

i. Early retirement

$(42.9 \%$ / N=1,042)

ii. On-time retirement

$(23.2 \% / \mathrm{N}=560)$

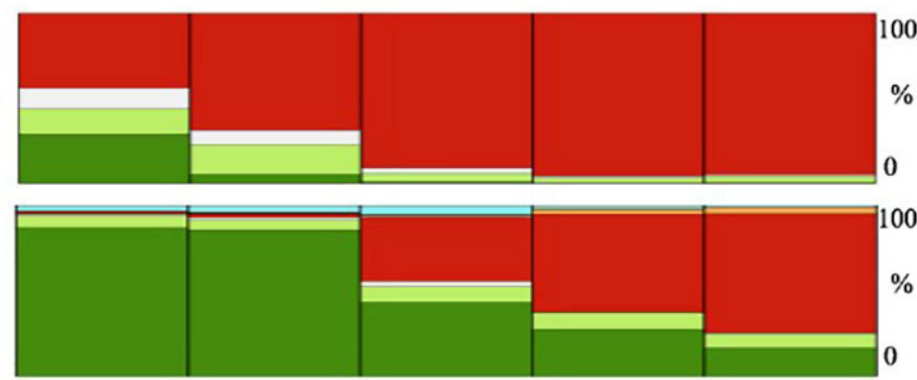

Labor-force statuses

Working

Full-time

Working

Part-time

Out of the

Labor Force

iii. Late retirement

$(9.8 \%$ / $\mathrm{N}=239)$

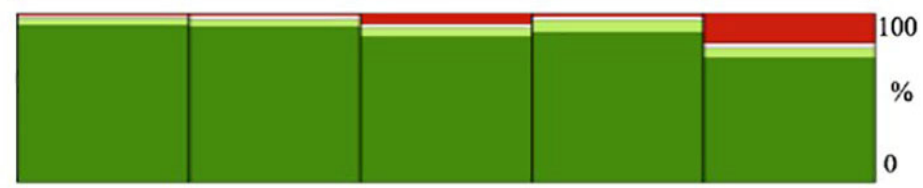

Retired

iv. Part-time work

$(9.6 \% / \mathrm{N}=233)$

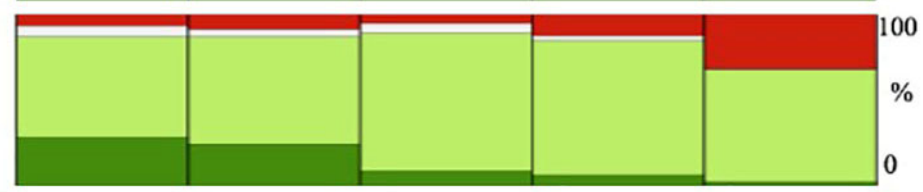

v. Not in the labor market

$(14.7 \%$ / N=357)

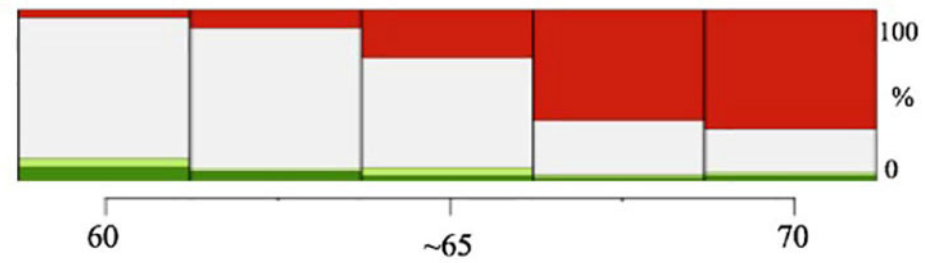

Age 